\title{
People-Plants Interaction and Its Uses: A Science of Four Words "Ethnobotany"
}

\author{
Farhana ljaz, Zafar Iqbal, Inayat Ur Rahman, Niaz Ali", Muhammad Afzal
}

Department of Botany, Hazara University, Mansehra, KP, Pakistan

*Corresponding author: Niaz Ali, Department of Botany, Hazara University, Mansehra, KP, Pakistan, Tel: +923139435319; E-mail: niazalitk25@gmal.com

Received date: February 23, 2017; Accepted date: March 24, 2017; Published date: March 27, 2017

Copyright: ( 2017 ljaz F, et al. This is an open-access article distributed under the terms of the Creative Commons Attribution License, which permits unrestricted use, distribution, and reproduction in any medium, provided the original author and source are credited.

Keywords: Ethnobotany, Medicinal plants

\section{Commentary}

Ethnobotany is the study of plants to know their usages that how people practice them $[1,2]$. The significance and uses of plants either medicinally or else their occurrence within confined environments depends upon the notion of people. Since the beginning of civilization, both the Babylon (1770 BC) and the pre-historic Egyptian age (ca. 1550 BC) signifies the usage of medicinal plants. The prehistoric Egyptians believed that medicinal plants were very valuable for their Pharaohs (Egyptian king) in their next life after death [3].

A question arises in everyone's mind, how people use plants and what are the reasons they use them? To solve this problem ethnobotanists collect information from existing individuals [4]. In this way, an appreciable data regarding the current uses of plant species as well as their associated importance for construction, food and/or medication in their ancient actuality is gained. It also gives an idea of people's old-style natural knowledge especially related to plants and the effect of this knowledge on the research and methods used in ethnobotany. After a lecture of Dr John Hershberger at Philadelphia in 1895 , where he used the term "ethnobotany" to pronounce the field of study, namely: "the study of plants used by primitive and aboriginal people" [5]. The thought of ethnobotany started to progress and that continues to this day. Robbins et al. [5] investigating the following questions: in which the "study of natural uses of plants" is replaced by the term "ethnobotany". What are original ideas and formations of plant life, and the possessions of a given plant situation on the lives, civilizations, religion, beliefs of people. Additionally, how plants have been used for traditional purposes, food, treatments, and material culture and what is the level of their knowledge of the quantities, functions and role. These queries are still valid and related to current ethnobotanical exploration.

Jones [6] addressed the basis for future regression of ethnobotany in pointing out that ethnobotany is entirely disturbed with the interrelation of simple man and plants. Ethnobiology promoted by Castetter [7] and suggested several strategies for investigators. These recommendations encompasses: plant documentation, comparative richness and accessibility of the plants, local names of plants, purposes of use, season of collection, whether or not the plant is inherent to the area, their commercial importance, species not used in the region and importance of the plant in the economy or culture.

Later on, Jone's definition was reframed by Ford [8] to accommodate the developments of the field and established that "Ethnobotany is the study of the direct inter-relations between humans and plants". The conjunction of the term "direct" admitted those who were in persistent interaction with plants, allowing them to organize in their way and to produce traditional rules for influencing plants in their confined environments. The omission of "primitive" is certified extension of the ground study. Ethnobotany at this point is concerned with the traditional facts of predominantly non-western people. Ethnobotany sustains a multidisciplinary character: botanically, focuses on the plant and plant uses, although ecological patterns, plant distributions, resources consumption and agricultural and cultivated designs have gained popularity amongst the ethnobotanists [3].

Anthropologically, ethnobotanists focus on realizing human collaborations with plants through original symbols, folklore, ceremonies and plant categorizations among non-western peoples [9]. Historically, ethnobotanists accentuated on agronomic origins and ancient plant uses and relied on plant and coprolite remains fossilized pollen and old food stores to regulate primitive plant uses and associations [10]. Recently, ethnobotanists have developed a holistic approach of relying on several key concepts in order to conduct their investigation, comprising data from botany, musicology, architecture, linguistics, pharmacology, anthropology, conservation biology and many others, depending on the questions being answered in the study [11]. Ecological associations within the plant community are essential to these studies as well as the more plant-human relationship in relations of community economics. Here, anthropological economic theory plays an important role in a way that helps the ethnobotanists to precisely measure and calculate human necessities and their influence on a confined environment.

Ethnobotanists through close interaction with plants of an area are capable of relying local and specific upon plant nomenclatures and to study all the physical assets of the plants. They pay courtesy to traditionally related conceptual and representative properties of plants in a specific area. In this regard, the ethnobotanists developed and designed many statistical indices due to which conventional ethnobotany [1] further renowned as quantitative ethnobotany [12-16]. In such studies, not only the plant's traditional uses or folk recipes but, their most preferable uses, traditional use values, rankings and importance etc. are also addressed. Furthermore, such studies specifically focuses ethnomedicines, and are of much interest as it provides the baseline for future work and specifies the important and most targetable plant species for further evaluation, proper experimentation and pharmacological activities to authenticate their traditional usage.

\section{Dedication}

The authors dedicate this work to Dr. Muhammad Afzal whose sudden death on March 19, 2017 shocked and devastated everyone. You will forever be remembered, missed and loved.

\section{References}

1. Ijaz F, Iqbal Z, Alam J, Khan SM, Afzal A, et al. (2015) Ethno medicinal study upon folk recipes against various human diseases in Sarban Hills, Abbottabad, Pakistan. World J Zoology 10: 41-46. 
Citation: Ijaz F, Iqbal Z, Ur Rahman I, Ali N, Afzal M (2017) People-Plants Interaction and Its Uses: A Science of Four Words "Ethnobotany". Altern Integr Med 6: 235. doi:10.4172/2327-5162.1000235

Page 2 of 2

2. Ijaz F, Iqbal Z, Rahman IU, Alam J, Khan SM, et al. (2016) Investigation of traditional medicinal floral knowledge of Sarban Hills, Abbottabad, KP, Pakistan. J Ethnopharmacol 179: 208-233.

3. Veilleux C, King SR (1996) An introduction to ethno botany. Linda Morgenstem editor.

4. Rahman IU, F Ijaz, Iqbal Z, Afzal A, Ali N, et al. (2016) A novel survey of the ethno medicinal knowledge of dental problems in Manoor Valley (Northern Himalaya), Pakistan. J Ethnopharmacol 194: 877-894.

5. Robbins WW, Harrington JP, Freire-Marreco B (1916) Ethnobotany of the Tewa Indians Bureau of American Ethology Bulletin 50.

6. Jones VH (1941) The nature and scope of ethnobotany. Chronica Botanica 6: 219-221.

7. Castetter EF (1944) The domain of ethnobiology. American Naturalist 78 158-171.

8. Ford RI (1978) Ehnobotany: Historical diversity and sythesis: The nature and status of ethnobotany. Anthropological Papers 67.

9. Atran S (1985) The Nature of Folk-Botanical Life Forms. American Anthropologist 87: 298-315.

10. Kaplan EH (1963) Empiricism as a function of training in the scientific method. J Res Sci Teach 1: 329-240.
11. Turner NJ, Davis (1993) 'When everything was scarce'; The role of plants as famine food in northwestern north America. J Ethnol 13: 1-28.

12. Rahman IU, Ijaz F, Afzal A, Iqbal Z, Ali N, et al. (2016) Contributions to the phytotherapies of digestive disorders; Traditional knowledge and cultural drivers of Manoor Valley, Northern Pakistan. J Ethnopharmacol 192: 30-52.

13. Rahman IU, Ijaz F, Iqbal Z, Afzal A, Ali N, et al. (2016) Graphical dataset on important medicinal plants used for curing dental issues in Manoor Valley, Mansehra, Pakistan. Data Brief 9: 1028-1033.

14. Muhammad S, Hussain M, Rahman IU, Shah GM, Ijaz F, et al. (2016) Indigenous medicinal usage of family Asteraceae in Sadda Lower Kurram Agency: A Case Study. Asian J Sci \& Technol 7: 3998-4003.

15. Khattak NS, Nouroz F, Rahman IU, Noreen S (2015) Ethno veterinary uses of medicinal plants of district Karak, Pakistan. J Ethnopharmacol 171: 273-279.

16. Khan KU, Shah M, Ahmad H, Ashraf M, Rahman IU, et al. (2015) Investigation of traditional veterinary phytomedicines used in Deosai Plateau, Pakistan. Global Vet 15: 381-388. 